\title{
Comparative Developmental and Susceptibility to Insecticide of Bolivian and Brazilian Populations of Triatoma infestans
}

\author{
Herton Helder Rocha Pires ${ }^{+}$, Silvia Ermelinda Barbosa, Liléia Diotaiuti
}

Laboratório de Triatomíneos e Epidemiologia da Doença de Chagas, Centro de Pesquisas René Rachou-Fiocruz, Av. Augusto de Lima 1715, 30190-002 Belo Horizonte, MG, Brasil

The triatomine bug Triatoma infestans probably originated in Bolivia and dispersed passively over wide areas of South America, where it is the principal vector of Trypanosoma cruzi. In the region of its probable origin this species shows colonization in two different ecotopes, so that it may be encountered in sylvatic as well as in artificial habitats. The sylvatic colonization pattern is not observed in the rest of its range, where T. infestans is exclusive to man-made habitats. The objective of this study was to compare several aspects of two T. infestans populations, one from Minas Gerais (Brazil) and the other from the Cochabamba Valley (Bolivia), with a view to elucidate the factors associated with the different colonization patterns observed for this species. The differences between the developmental cycle, weight, capacity to ingest blood and mortality rate of first instar nymphs should indicate more fragility of Brazilian population that may be related to its elimination possibility.

Key words: Triatoma infestans - populations - developmental cycle - insecticides

Triatoma infestans (Klug) (Hemiptera, Reduviidae, Triatominae) is believed to have originated from the Cochabamba region of central Bolivia, where it can be found in silvatic habitats under rockpiles, as well as in peridomestic and domestic habitats. In other locations, including Brazil, $T$. infestans appears to have been introduced by passive dispersal as a predominantly domestic species (Neiva 1913, Dujardin et al. 1987, Schofield 1994), and is found only in human dwellings and peridomestic habitats. Dujardin et al. (1998) used enzymatic comparisons to demonstrate the limited genetic differences between neighbouring populations of $T$. infestans, suggesting a recent and relatively rapid dispersal of this species from its presumed Bolivian origin. We have previously found morphological differences between $T$. infestans from Bolivia and Brazil (Pires et al. 1998) and we present here evidence for biological differences between $T$. infestans populations from the two regions.

\section{MATERIALS AND METHODS}

Two T. infestans populations were studied. The first of these descended from insects captured in-

\footnotetext{
Financial support: Fiocruz, Eclat and CNPq

${ }^{+}$Corresponding author. Fax: +55-31-295.3115. E-mail: tim@cpqrr.fiocruz.br

Received 14 December 1999

Accepted 28 June 2000
}

side houses in northern Minas Gerais (municipalities of Itacarambi, Manga and Montalvânia) (Brazilian colony) and the other from individuals collected in peridomestic ecotopes of Cochabamba in 1991 (Bolivian colony).

The two colonies had been maintained in the insectary of the Centro de Pesquisas René Rachou under semi-controlled conditions of temperature and humidity $\left(27 \pm 2^{\circ} \mathrm{C}\right.$ and $\left.60 \pm 5 \% \mathrm{RH}\right)$, fed on chickens (Gallus gallus) once per week. In the present study the triatomines were fed on albino mice (Swiss webster, Mus musculus), anesthetized with thionembutal.

Developmental cycle - The embryonic phase was studied in 40 recently deposited eggs from each colony. The eggs were weighed and subsequently maintained in isolation, enabling each nymph to be identified by its eclosion date.

The development of the other instars was observed using 40 recently emerged first-instar nymphs of each colony, placed individually in small plastic containers and fed weekly for $30 \mathrm{~min}$. The dates of first feeding in each instar and moulting to the subsequent instar were noted.

Weight of each instar - Thirty nymphs of each of the five instars, together with 30 males and 30 females of each colony were weighed. These triatomines were separated in the previous instar and weighed immediately after eclosion and ecdysis.

Volume of blood ingested by third instar nymphs - Third-instar nymphs of each of the colo- 
nies were separated immediately after ecdysis and maintained individually in plastic containers. A blood meal was offered after seven days, for 30 $\min$. The triatomines were weighed before and after the blood meal.

Crossing between insects of the two colonies Male and female fifth-instar nymphs from both colonies were isolated individually, according to Corrêa (1954), thus guaranteeing the virginity of the females until the imaginal moult, when they were paired according to the scheme described below. The insects were fed once a week. Oviposition was observed each week, the eggs from each female being kept isolated to verify fertility of each pair. Thirty first instar nymphs of these lines were weighed on the date of eclosion.

Scheme for pairing between insects of the two colonies: Group 1 - Female of Brazilian colony with male of Brazilian colony; Group 2 - Female of Brazilian colony with male of Bolivian colony; Group 3 - Female of Bolivian colony with male of Bolivian colony; Group 4 - Female of Bolivian colony with male of Brazilian colony.

Four pairings were carried out in groups 2, 3 and 4 ; and three pairings were carried out in group 1 .

Susceptibility to insecticide - Thirty first-instar nymphs of each of the two colonies were treated with $2 \mu \mathrm{l}$ of $100 \%$ technical grade deltamethrin in acetone, applied topically to the ventral surface of the abdomen, at $0.3 \mu \mathrm{g}$ of deltamethrin per grams of body weight, corresponding to the knock-down dose determined by Colas and Delabarre (1983). An equal number of individuals of each population was treated with $2 \mu \mathrm{l}$ of acetone alone, as control. The nymphs were maintained individually in plastic vials $(3.8 \mathrm{~cm}$ high, diameter 3.5$)$, which permitted them to move around. Observations were carried out by one person, initiated one hour after contact with the insecticide and thereafter every $24 \mathrm{~h}$ over a period of 15 days. The triatomines were assigned categories normal, intoxicated, paralyzed and/or dead according to the following criteria: 1 Normal triatomines did not show any motor disturbance and moved normally around a Petri dish (14 cm diameter) lined with filter paper; 2 Triatomines were considered to be intoxicated if they showed any type of alteration in their behaviour but were still able to walk around in the Petri dish; 3 - Triatomines were considered to be paralyzed and/or dead if they did not move the legs and antennae without being prodded or remained totally inert even when the appendages were stimulated.

Fifth-instar nymphs were chosen for the assays due to their reported highest resistance to insecticides (Zerba et al. 1985).
Statistical analysis - The distribution of each of the continuous variables was tested for normality by the Kolmogrorov-Smirnov test. Differences between both groups of bugs in duration of each nymph stage, time taken to moult after blood intake and nymph weight at each stage, blood intake at third stage and mean time of eclosion, were tested by Student- $t$ test or its non-parametric alternative (Kruskall-Wallis). Differences in weight of eggs resulting from the different crosses were tested by analysis of variance.

For the test of susceptibility to insecticide, a $\chi^{2}$ test was done to verify any differences in intoxication of the bugs of different colonies.

The levels of significance accepted were of $\mathrm{p} \leq 0.05(95 \%)$.

\section{RESULTS}

The mean egg weight from the Brazilian and Bolivian colonies was $2.04 \pm 0.27$ and $2.56 \pm 0.54$ $\mathrm{mg}$, respectively ( $t$-test, $\mathrm{p}<0.01$ ). There was also a significant difference in the eclosion times, $20.97 \pm 0.54$ days for the Brazilian colony compared with $22.43 \pm 1.04$ days for the Bolivian colony (Kruskall-Wallis, $\mathrm{p}<0.01$ ).

Although there was no significant difference in the time that the triatomines of the two colonies spent at each nymphal instar ( $t$-test and KruskallWallis) the mean total duration of post-embryonic development was different, $183.47 \pm 21.18$ days for the Brazilian colony and $173.85 \pm 19.59$ days for the Bolivian colony ( $t$-test $\mathrm{p}=0.05$ ) (Table I).

There was no significant difference between the colonies with respect to the time intervals between feeding and moulting to the subsequent instar $(t$ test and Kruskal-Wallis, Table II).

Ten insects $(25 \%)$ of the Brazilian colony did not complete the developmental cycle, dying before reaching the adult stage. Eight died in the first instar, one in the fourth and one in the fifth. For the Bolivian colony only one insect did not complete this cycle, dying as a first instar nymph. These differences in mortality are statistically significant $\left(\chi^{2}, \mathrm{p}=0.01\right)$.

The insects of the Bolivian colony were significantly heavier in each of the instars than those of the Brazilian colony ( $t$-test, $\mathrm{p}<0.01$, Table III).

The mean quantity of blood ingested by the third instar nymphs of the Brazilian colony was $38.43 \pm 27.08 \mathrm{mg}$, significantly less than the $58.14 \pm 28.84 \mathrm{mg}$ ingested by insects of the Bolivian colony ( $t$-test, $\mathrm{p}=0.01$ ).

Crosses between insects of the two colonies All the females began oviposition 4-5 weeks after mating. No significant difference was observed in the eclosion success of the resulting eggs among the four groups of insects during the first eight weeks 
after mating $\left(\chi^{2}, \mathrm{p}=0.81\right)$ (Tables IV). Furthermore there was no difference in the weights of nymphs descended from Brazilian females paired with Brazilian or Bolivian males ( $t$-test, $\mathrm{p}=0.8)$, or between those descended from Bolivian females paired with Bolivian or Brazilian males ( $t$-test, $\mathrm{p}=0.6$ ). However a statistically significant difference was observed between the weights of the nymphs descended from Brazilian females when compared with those of the Bolivian females, irrespective of the origin of the males ( $t$-test, $\mathrm{p}<0.01$, Table V).

The insects of the first generation resulting from crosses between the two colonies were fertile, giving rise to a second generation.

\section{TABLE I}

Mean time (days) that triatomines of two colonies (Brazilian and Bolivian) remained in each instar and total development time (first instar - adult), from 40 eggs of each colony

\begin{tabular}{lccl}
\hline Developmental stage & Brazilian colony & Bolivian colony & P (test) \\
\hline I & $33.25 \pm 13.74$ & $25.83 \pm 7.21$ & 0.01 (Kruskal Wallis) \\
II & $27.38 \pm 8.76$ & $29.85 \pm 7.54$ & 0.21 (Kruskal Wallis) \\
III & $28.63 \pm 6.73$ & $29.87 \pm 10.04$ & 0.54 (Kruskal Wallis) \\
IV & $34.69 \pm 7.56$ & $34.80 \pm 7.89$ & $0.95(t$-test) \\
V & $58.39 \pm 16.57$ & $53.41 \pm 14.09$ & $0.18(t$-test) \\
I / adult & $183.47 \pm 21.18$ & $173.85 \pm 19.59$ & $=0.05(t$-test) \\
\hline
\end{tabular}

TABLE II

Mean time (days) that triatomines of the two colonies (Brazilian and Bolivian) took to reach ecdysis, after the last blood meal, from 40 first-instar nymphs of each colony

\begin{tabular}{lccl}
\hline Ecdysis & Brazilian colony & Bolivian colony & $\mathrm{P}$ \\
\hline I to II & $17.00+6.89$ & $15.15+3.74$ & 0.18 (Kruskal-Wallis) \\
II to III & $19.94+8.84$ & $18.90+2.99$ & 0.53 (Kruskal-Wallis) \\
III to IV & $22.50+4.89$ & $23.68+8.08$ & 0.45 (Kruskal-Wallis) \\
IV to V & $28.69+8.46$ & $25.35+7.92$ & $0.09(t$-test) \\
V to adult & $44.94+12.14$ & $41.68+12.62$ & $0.28(t$-tst) \\
\hline
\end{tabular}

TABLE III

Mean weight (mg) of triatomines of the two colonies (Brazilian and Bolivian) in each of the developmental stages following ecdysis

\begin{tabular}{lccr}
\hline Developmental stage & Brazilian colony & Bolivian colony & $P(t$-test $)$ \\
\hline I & $1.45 \pm 0.28$ & $2.51 \pm 0.46$ & $<0.01$ \\
II & $5.31 \pm 0.70$ & $6.67 \pm 0.75$ & $<0.01$ \\
III & $14.72 \pm 2.20$ & $19.70 \pm 3.62$ & $<0.01$ \\
IV & $34.71 \pm 6.56$ & $43.30 \pm 8.93$ & $<0.01$ \\
V & $69.73 \pm 15.01$ & $122.61 \pm 16.92$ & $<0.01$ \\
Adult females & $165.84 \pm 37.02$ & $295.20 \pm 68.50$ & $<0.01$ \\
Adult males & $163.23 \pm 52.14$ & $283.41 \pm 34.87$ & $<0.01$ \\
\hline
\end{tabular}

TABLE IV

Number of eggs laid, number of eggs hatched and percentage fertility for crosses between Triatoma infestans from Brazilian and Bolivian colonies, up to 8th week after mating

\begin{tabular}{lccc}
\hline & Total number of eggs laid & Number of eggs hatched ${ }^{a}$ & $\%$ hatch \\
\hline Group 1 $(n=3)$ & 154 & 89 & $57.8 \%$ \\
Group 2 $(n=4)$ & 214 & 131 & $61.2 \%$ \\
Group 3 $(n=4)$ & 297 & 171 & $57.6 \%$ \\
Group 4 $(n=4)$ & 262 & 150 & $57.3 \%$ \\
\hline
\end{tabular}

Group 1: female of Brazilian colony with male of Brazilian colony; group 2: female of Brazilian colony with male of Bolivian colony; group 3: female of Bolivian colony with male of Bolivian colony; group 4: female of Bolivian colony with male of Brazilian colony; $\mathrm{n}$ : number of couple; $a$ : $\chi^{2}$-test $(\mathrm{p}=0.81)$ 


\section{TABLE V}

Mean weight in milligrams of first instar nymphs, offspring of crosses between Brazilian and Bolivian colonies of Triatoma infestans

\begin{tabular}{lcc}
\hline & Brazilian females & Bolivian females \\
\hline Brazilian males & $1.41 \pm 0.38$ & $2.37 \pm 0.24$ \\
Bolivian males & $1.39 \pm 0.27$ & $2.33 \pm 0.33$ \\
\hline
\end{tabular}

Susceptibility to insecticide - Susceptibility tests for deltamethrin revealed that after 15 days, seven insects of the Brazilian colony (23.3\%) and five of the Bolivian one $(16.6 \%)$ had died. The rest of the insects of the two colonies showed some symptom of intoxication. There was no difference in the number of dead and intoxicated insects between the two colonies $1 \mathrm{~h}$ after application of the insecticide, nor after seven or 15 days $\left(\chi^{2}, \mathrm{p}=0.11\right.$, $\mathrm{p}=0.29, \mathrm{p}=0.74$ respectively).

There were statistically significant differences between the mortality rates of the control and test groups for both colonies $\left(\chi^{2}, \mathrm{p}<0.01\right)$.

\section{DISCUSSION}

The weight of insects of the Bolivian colony (F3) was consistently greater than those of the Brazilian one. According to Perlowagora-Szumlewicz et al. (1973), the mean weights of the five nymphal stages of $T$. infestans are 1.65, 6.3, 16.2, 46.7 and $116.4 \mathrm{mg}$, adult males and females averaging 177.3 and $260.6 \mathrm{mg}$ respectively. The members of the Brazilian colony always weighed less than these values while the Bolivian insects were always heavier, except in the fourth instar.

Based on studies of crosses between insects of the two populations, it was observed that the weight of first-instar nymphs was related to the size of the female progenitors, independently of the origin of the males, probably reflecting the average egg size of these females.

Perlowagora-Szumlewicz (1969) observed that the mean volume of blood ingested in the first meal of $T$. infestans following the moult to third instar was $45.4 \mathrm{mg}$. Cerisola et al. (1974) recorded a corresponding value of $55.5 \mathrm{mg}$, the nymphs having the capacity to ingest five times the initial body weight. The mean quantity of blood ingested by third-instar nymphs of the Brazilian colony was less $(38.43 \pm 27.08 \mathrm{mg})$ than the values observed by these authors, although that ingested by nymphs of the Bolivian colony was greater $(58.14 \pm 28.84$ $\mathrm{mg}$ ), possibly indicating a proportional relationship to the size of the insects.

The duration of embryonic development of triatomines is directly related to environmental variations in temperature and relative humidity
(Juarez 1970, Ronderos 1972). PerlowagoraSzumlewicz (1953), studying a population of $T$. infestans from Minas Gerais, observed that eggs maintained at $24-28^{\circ} \mathrm{C}$ began to hatch 11 days after oviposition, reaching a peak after 17-20 days. Hack (1955) reared T. infestans under laboratory conditions and in incubators at $25^{\circ}$ and $33^{\circ} \mathrm{C}$ and found the durations of the embryonic phases to be 27-46, 20-24 and 11-13 days, respectively. Juarez (1970) obtained a mean of 27.3 days for the appearance of nymphs maintained at $25^{\circ} \mathrm{C}$ and 14.4 days for those kept at $30^{\circ} \mathrm{C}$. In the present study the Brazilian colony took a mean of 20 days to initiate eclosion of the eggs, while the Bolivian colony took 22 days, when both were maintained at temperatures varying from $21-31^{\circ} \mathrm{C}$ and $\mathrm{RH}$ of $60-65 \%$. We believe that the difference between our results and those of Perlowagora-Szumlewicz (1953) may be due to environmental climatic variations, as well as biological factors related to the insects themselves. Statistically significant differences can be observed between the results obtained for the two populations, with insects of the Brazilian colony developing more rapidly. As the eggs of Bolivian triatomines are larger, we believe that this difference occurs due to factors linked to their structure and that of the embryos.

Post-embryonic development is directly linked to feeding success and consequently the secretion of hormones, stimulated by expansion of the nymphal abdomen and influenced by temperature and relative humidity of the air. Neiva (1913) studied the development of $T$. infestans in the laboratory and observed a duration of 220-240 days. Abalos and Wygodzinsky (1951) stated that the egg to adult cycle was completed in 240 days, although Perlowagora-Szumlewicz (1969) was able to rear this species in only 84-134 days at temperatures varying from $20-28^{\circ} \mathrm{C}$. This period may be further reduced with an increase in temperature, according to the observations of Hack (1955), who obtained adults in 66 days at $33-35^{\circ} \mathrm{C}$. Perlowagora-Szumlewicz (1953) obtained the same results by maintaining her insects at $24-28^{\circ} \mathrm{C}$, although she also increased the frequency of feeding to once every 4-5 days. Similar results were obtained by Zerba et al. (1985), at $33-35^{\circ} \mathrm{C}$. Gorla and Schofield (1985) observed the occurrence of two peaks of emergence for adult $T$. infestans during the year, development time being approximately six months. In the present study the mean time taken to complete the developmental cycle was close to the six months average for both colonies, but differed significantly at $183.47 \pm 21.18$ days for the Brazilian colony and 173.85 \pm 19.59 days for the Bolivian colony. As modelled by Schofield (1980) such differences can markedly 
influence the reproduction rate of the respective populations.

Perlowagora-Szumlewicz (1975) stated that first instar nymphs of $T$. infestans, maintained at $24-28^{\circ} \mathrm{C}$, were able to feed on blood from the fourth day after hatching onwards. Obtaining the first meal during this period ensures that the insects have a greater chance of reaching the adult stage. According to this author the first meal regulates the time and the percentage of the first moults, subsequent meals diminishing in importance. In the present study it was observed that some first instar nymphs refused to feed, dying without taking a blood meal. The percentage of insects that showed this behaviour was different for the two colonies, being 20\% (eight insects) for the Brazilian colony and $2.5 \%$ (one insect) for the Bolivian one (F3). Locke (1958) observed that the size of all instars of Rhodnius prolixus Stal, 1859 may be affected by occurrences during the previous instar. Thus in the present study the reduced capacity of Brazilian first-instar nymphs of the Brazilian population to feed may result in a reduction in the body size of the subsequent instars.

Regis (1979) observed that the rhythm of egg laying is regulated by the nutritional status of the females. The number of eggs produced by a female $T$. infestans is proportional to the quantity of blood ingested, each egg requiring the equivalent of approximately $17 \mathrm{mg}$ (Regis 1977, 1979). Gorla and Schofield (1989) observed that the rhythm of egg production by $T$. infestans may vary according to the time of the year, being greater in the warmer period from September to March. In the present study no differences were observed between insects of the two colonies in the quantity of eggs laid or in the percentage fertility, each of them giving rise to a fertile first generation $(\mathrm{F} 1)$.

The susceptibility of the insects to deltamethrin were not significantly different between both colonies. However, the longer developmental time and the higher mortality of the insects of the Brazilian colony agrees with field data that reveal, in a general manner, an ease to have success eliminating T. infestans at Minas Gerais (Schofield \& Dias 1999). This fact could be related to the hypothesis of genetic simplification to which triatomines are subjected in the process of adaptation to domiciles, proposed by Schofield (1994), in which the $T$. infestans from Brazil represent a high level of specialization to intradomiciliar environments.

\section{ACKNOWLEDGEMENTS}

To Jolandt Disch for the statistical analysis.

\section{REFERENCES}

Abalos LW, Wygodzinsky P 1951. Las Triatominae Argentinas (Reduviidae, Hemipterae), Monograph
2, Universidade Nacional de Tucumán, Instituto de Medicina Regional, 179 pp.

Cerisola JA, Rohwedder R, Segura EL, Del Prado CE, Alvarez M, De Martini GJW 1974. El Xenodiagnostico, Ministerio de Bienestar Social, Buenos Aires, 84 pp.

Colas R, Delabarre M 1983. Destruccion de los vectores de grandes enfermedades endemicas. In Deltametrín, Monograph, p. 261-273.

Corrêa RR 1954. Estudos sobre a morfologia esterna do gênero Triatoma laporte, 1833 (Hemiptera, Reduviidae). Fol Clin Biol 22: 23-50.

Dujardin JP, Schofield CJ, Tibayrenc M 1998. Population structure of Andean Triatoma infestans: allozyme frequencies and their epidemiological relevance. Med Vet Entomol 12: 20-29.

Dujardin JP, Tibayrenc M, Venegas E, Maldonado L, Desjeux P, Ayala FJ 1987. Isoenzyme evidence of lack of speciation between wild and domestic $T$. infestans (Heteroptera: Reduviidae) in Bolivia. J Med Entomol 24: 40-45.

Gorla DE, Schofield CJ 1989. Population dynamics of Triatoma infestans under natural climatic conditions in the Argentine Chaco. Med Vet Entomol 3: 179194.

Hack WH 1955. Estudios sobre biología del Triatoma infestans (Klug, 1834) (Hemiptera, Reduviidae). Universidade Nacional de Tucumán. An Inst Med Reg 4: 125-147.

Juarez E 1970. Comportamento do Triatoma infestans sob várias condições de laboratório. Rev Saú Púb 4: 147-166.

Locke M 1958. The formation of tracheae and tracheoles in Rhodnius prolixus. Q J Microsc Sci 99: 29-46.

Neiva A 1913. Informação sobre a biologia da vinchuca Triatoma infestans Klug. Mem Inst Oswaldo Cruz 5: 31 .

Perlowagora-Szumlewicz A 1953. Ciclo evolutivo do Triatoma infestans em condições de laboratório. Rev Bra Malariol D Trop 5: 35-48.

Perlowagora-Szumlewicz A 1969. Estudo sobre a biologia do $T$. infestans, o principal vetor da doença de Chagas no Brasil (Importância de algumas de suas características biológicas no planejamento de esquemas de combate a esse vetor). Rev Bras Malariol D Trop 21: 117-159.

Perlowagora-Szumlewicz A 1975. Laboratory colonies of Triatominae, biology and population dynamics. PAHO Sci 318: 63-82.

Perlowagora-Szumlewicz A, Cruz HN, Araújo JAN 1973. Species and stage interaction in the feeding behavior of vectors of Chagas disease (The importance of determinants in planning for greater efficacy and standardization of xenodiagnostic procedures). Rev Inst Med Trop São Paulo 15: 139-150.

Pires HHR, Barbosa SE, Margonari C, Jurberg J, Diotaiuti L 1998. Variations of the external genitalia in three populations of Triatoma infestans Klug, 1834. Mem Inst Oswaldo Cruz 93: 479-483.

Regis L 1977. Nutrition et Fecondité chez Triatoma infestans (Heteroptera, Reduviidae), These, 3e cycle, Univ. Paris VI, France, 91 pp. 
Regis L 1979. The role of the blood meal in egg-laying periodicity and fecundity in Triatoma infestans. Inst J Invertebr Reprod 1: 187-195.

Ronderos RA 1972. Biologia de triatomíneos. Symposium Internacional sobre Enfermedad de Chagas, Sociedad Argentina de Parasitologia, $1^{\circ}$ Congresso Argentino de Parasitologia Buenos Aires, Argentina, p. 321-326.

Schofield CJ 1980. Density regulation of domestic populations of Triatoma infestans in Brazil. Trans $R$ Soc Trop Med Hyg 74:761-769.

Schofield CJ 1994. Triatominae - Biologia y Control,
Eurocommunica Publications, West Sussex, UK, 78 pp.

Schofield CJ, Dias JCP 1999 The Southern Cone initiative against Chagas disease. Adv Parasitol 42: 1-27.

Zerba EN, Licastro SMA, Wood EJ, Villar MIP 1985. Modo de insecticidas en Triatoma infestans. In RV Carvalho, JE Rabinovich, RJ Tonn, Factores Biologicos y Ecologicos en la Enfermidad de Chagas, Centro Panamericano de Ecologia Humana y Organización Panamericana de la Salud, Serviço Nacional de Chagas, Ministerio de Salud y Acción Social, República Argentina, p. 309-318. 